\title{
PLACE NAMES AND IDENTITIES: THE USES OF NAMES OF HELSINKI
}

\author{
TERHI AINIALA \\ Research Institute for the Languages of Finland
}

\section{A B S T R AC T}

The paper discusses the use of names that are used to refer to Helsinki, the capital of Finland. Three research questions are studied: Firstly, which name variants do the Helsinkians claim they use about their own home city? Secondly, how do they rationalize and explain their name use or non-use? And thirdly, in what ways do the self reported use and the spontaneous use of name variants differ from each other? The explanations for the use or non-use of specific name variants are often attached to the speaker's identity.

\section{[1] INTRODUCTION}

This paper discusses the use of names that are used to refer to Helsinki, the capital of Finland. Three research questions are studied: Firstly, which name variants do the Helsinkians claim they use about their own home city? Secondly, how do they rationalize and explain their name use or non-use? And thirdly, in what ways do the self reported (metalinguistic) use and the spontaneous use of name variants differ from each other? The explanations for the use or non-use of specific name variants are often attached to the speaker's identity. Thus, this paper also explores the relationship between the use of place names and social identity. Social identity contains self-descriptions derived from memberships of social categories, including nationality, gender, ethnicity, occupation or hobby groups (Hogg \& Abrams 1988, 24-25). The most important and relevant social feature in this study is the place of birth, i.e. a native city dweller's identity vs. the identity of a person having moved to the city from elsewhere. Nevertheless, it is crucial to understand that we all belong to multiple social categories at the same time. The number of social identities varies from person to person, just as their combinations. Although different social identities may sometimes show tension, they are usually connected to each other somehow. (Verkuyten 2005, 50-51). ${ }^{1}$

[1] The article "Place names in the construction of social identities: the uses of names of Helsinki" by Ainiala published in the Proceedings of twenty-third International Congress of Onomastic Sciences (Toronto) studies the same problem but with different examples and slightly different data. 


\section{[2] RESEARCH DATA}

The present study is based on a research project titled "Transformation of onomastic landscape in the sociolinguistically diversifying neighbourhoods of Helsinki", carried out at the Research Institute for the Languages of Finland. The project investigates the historical and current onomastic landscape of Helsinki from the viewpoint of toponyms (both official and unofficial) that the various social segments of the population use. Two case study neighbourhoods, Kallio and Vuosaari, are studied (Ainiala \& Vuolteenaho 2006, 59).

The research data consist of thirteen interviews, of which three were individual and ten focus group interviews. In all, twenty-eight Helsinki-dwellers were interviewed. All the informants were living in Vuosaari in eastern Helsinki. Nineteen of the informants had Finnish as their mother tongue, whereas nine were Somali immigrants and spoke Finnish as their second language or as a foreign language. Thus, I am going to comment briefly on how the use of place names differed between the native Finnish informants and the informants having another language as their mother tongue. In the group of nineteen Finnish speakers, eleven were native Helsinkians, whereas eight had moved to Helsinki from somewhere else in Finland. The interviews were made between 2004 and 2008. In every focus group there were between two and four participants talking about Helsinki. The discussions were taped and transcribed after the interviews. The transcription used is fairly rough and only gives the word-for-word description. All examples are translated from Finnish to English.

\section{[3] NAMES OF HELSINKI}

There are three main name variants for Helsinki in the material. The official name of the capital of Finland is Helsinki. The city was founded 1550 at the mouth of the river Vantaanjoki. The Swedish name Helsingfors was used to refer both to the city and the rapids of the river. Swedish was the major language in the area that time, since the largest part of the population was Swedish-speaking. It was only later that the city received its Finnish name Helsinki, in co-occurrence with the growing Finnish-speaking population. The first written documents concerning the name Helsinki date from the end of the eighteenth century (Paikkala 2007). In today's bilingual city, both Helsinki and Helsingfors are used, the latter one by the Swedish-speaking population, representing about six percent of the population in Helsinki. There were no Swedish-speaking informants in the present study.

The most common and widespread unofficial names for Helsinki are Hesa and Stadi. They both have their origins in Helsinki slang. Helsinki slang is a unique Creole dialect which evolved between 1890 and 1910 among the working class with both Finnish and Swedish language backgrounds in their densely occupied neighbourhoods in Helsinki. At the beginning of the twentieth century, the number of 
Swedish-speakers was much bigger than today. In 1910 Swedish-speakers represented 35 percent of the population in Helsinki (cf. today's six percent). Slang was born to facilitate bilingual communication. Phonologically it was closer to Swedish than Finnish and included the phonemes /b/, /d/, /g/ and /f/, which are not indigenous to Finnish. Slang names and words were usually composed by annexing a "slangifying" suffix to the root of the name (e.g. Fleminginkatu 'Fleming's Street' > Flemari). In contrast to the suffixes in standard Finnish, the slang suffixes did not have a semantic function of their own but they were simply used to make words and names slang-like (Paunonen 1994, 227, 237-238); (Paunonen 2000).

Eventually, in its later phases, gradually from the 1950s onwards, the old Helsinki slang gave way to a 'normal' Finnish-English-based slang of the younger generation throughout the Helsinki region. Even though the main user group and the function of the slang have changed, very many slang expressions and slang-based place names have remained the same from the very beginning of Helsinki slang, for over one hundred years (Paunonen 1994, 238); (Paunonen 2000).

Hesa derives from the official name Helsinki, which has been shortened and supplemented with the slang suffix $a$. The variant was known in Helsinki slang as early as the beginning of the twentieth century. According to the dictionary of Helsinki slang, Hesa belonged to the language use of native Helsinkians until the first half of the twentieth century (Paunonen (2000) s.v. Hesa.)

Stadi, in turn, has its origins in the Swedish word stad 'city, town'. Even Stadi has been in use in Helsinki slang ever since the beginning of the twentieth century. Traditionally, Stadi was used both to refer to a city or town generally and to Helsinki, especially the city centre. Stadi began to refer more and more often to Helsinki in the second half of the twentieth century. Hesa has been labeled more and more explicitly as a name variant used by peasants and non-native Helsinkians. Stadi thus carries the label of a name used by native Helsinkians (Paunonen (2000) s.v. Hesa, Stadi; (Vaattovaara \& Soininen-Stojanov 2006, 237). As will be seen in this paper, the research material partly confirmed, yet partly challenged the ideas and assumptions connected to the names Hesa and Stadi, and to their users.

\section{[4] THE NAMES THE INFORMANTS SAY THEY USE}

In the interviews, the informants were usually asked which name they used about Helsinki. In most cases the interviewer gave the three alternatives explicitly.

As the official name of the city Helsinki is the standard and neutral variant. It is only natural that most of the informants said they used it. However, as many as six out of the twenty-eight informants did not say they used the standard form Helsinki at all. I guess the informants must have regarded Helsinki so self-evident that they did not consider it essential to point it out in the interview. In addition, 
while answering the question about the name use, the informants did not necessarily think about the different name variants they used in various situations, but rather gave the name variants they felt corresponded to their identities most.

Unlike the official variant Helsinki, the unofficial name variants Hesa and Sta$d i$ are clearly affective in the material. I will first take a deeper look into what the interviews reveal about the use of Hesa. First of all, thirteen of the twenty eight informants said they used Hesa, i.e. almost half of all the informants. These thirteen informants included six native and five non-native Finnish-speaking and two Somali-speaking informants. ${ }^{2}$

In many interviews the traditional view that Hesa belongs to the language use of people living in the countryside and those who have moved to Helsinki from somewhere else was reinforced. In the following example (ex. 1) a non-native informant Tuula (born 1949) is having a conversation with her son Lauri (born 1985) and Lauri's friend Tuomas (born 1988). Both Lauri and Tuomas are native Helsinkians.

(1) Interviewer: So, if we like go right to the point now, let's start with Helsin$\mathrm{ki}$, so I'm asking you first what name you use about Helsinki.

Tuula: Hesa, of course.

Tuomas: People from the country say Hesa.

Lauri: Hesa and Stadi.

Tuomas: It's simply Stadi or Helsinki for me. I haven't I wouldnt, in my ears Hesa sounds nasty, since mom always says that country people say Hesa.

Tuula: Well no, I'm from the country, it suits me well enough.

Tuomas: It's Stadi or Helsinki.

Tuula: I moved there when I was nineteen, so I can say Hesa.

Lauri: Erm, I may have learnt it from you.

Tuula: Yeah.

Interviewer: Does it vary from one situation to another?

Tuomas: Yeah it does.

Lauri: Yeah if you talk to somebody, someone who's like from the country or something.

Tuomas: Do you know any people from the country?

Lauri: So then you'd say, you'd probably try to be polite, like you wouldn't use some of your own like code language, so you'd say Helsinki and the like, but otherwise to other people from Helsinki like Hesa and so on, like that.

[2] Finnish-speaking informant = informant, who has Finnish as her mother tongue; Somali-speaking = informant, who has Somali as her mother tongue. The same definitions are used throughout the article. 
Since Hesa is labelled as a name variant used by peasants, it is only natural that the native Helsinkians often avoid using it. This is exactly the case with Tuomas in the previous example.

Even though the name variant Hesa is regarded in the dictionary of Helsinki slang as being used by people from the country, there were six native informants who reported they used Hesa. Further, Hesa seems to be a common variant even in the collection of slang place names. This collection was compiled by interviewing teenage school children in Helsinki region in 2003. The material includes some 4 000 different place names used by teenagers and some 14500 different references to names (Ainiala 2006, 101). The name Hesa is mentioned 97 times in the material, which makes it the $18^{\text {th }}$ most popular name in the whole material (Ainiala 2004). Thus, the name variant Hesa seems to belong to the name usage of young Helsinkians of the $21^{\text {st }}$ century.

Likewise, two young Somali immigrants say they use Hesa, as well. In the following example (ex. 2) Abdi, a 22-year old Somali immigrant discusses the name variant Hesa.

(2) Interviewer: So then a bit more about the names like do you always say Helsinki and what other names you know for Helsinki than just Helsinki? Abdi: No other names.

Interviewer: I mean like anything young people would use or anybody else. Like would you just say that I'm going, I'm going to Helsinki. Or I'm going.. Abdi: To Hesa.

Interviewer: To Hesa. Yeah.

Abdi: Yeah.

Abdi has lived in Helsinki and Finland for 16 years, having moved to Finland as a child. Another Somali immigrant who said she used Hesa was Ayan, a 17-year old girl who had lived in Finland for ten years. They both spoke fluent Finnish and used slang words and other expressions typical of youth language. Accordingly, Hesa is a natural part of their vocabulary. In general, Hesa is part of the language use of young Helsinkians, both natives and non-natives, even though it is sometimes labeled as a rural variant, in contrast to Stadi. One of the obvious reasons for using Hesa is that it is short and thus an easy variant to use.

Stadi has traditionally been considered a name variant used by native Helsinkians (see ex. 1). Therefore, as expected, people who had moved to Helsinki from elsewhere did not seem to feel that Stadi was a natural variant for them, at least if they had not lived in Helsinki for long enough. In fact, a non-native informant Heidi (born 1985) makes the following ironic point in example 3:

(3) Heidi: Yeah, I certainly [use] Helsinki, and all, I'm not yet enough of a Stadi native to dare to use that. 
Out of the twenty eight informants in the material, almost every third, i.e. a total of ten people said they used Stadi. Of them, six were native (ex. 1) and three non-native Finnish-speakers, and one was Somali-speaking. A non-native informant who said she used Stadi was Tuula (born 1949), whom we know from example 1. In the following example (ex. 4) she says she uses even Stadi,in addition to Hesa.

Tuula says she is well aware of the fact that Stadi is associated with the language use of native Helsinkians and that non-natives should not even be allowed to use it.

A Somali immigrant who said she used Stadi - or at least recognized it, see the following example (ex. 5; see also ex. 7) - was Jasmin (born 1974), who moved to Helsinki (and Finland) in 1992 when she was 18 years old. She worked in a local youth centre with teenagers with different linguistic backgrounds, even Finnish, and was thus familiar with youth language and its typical place names.

(4) Interviewer: Do you remember any other word for Helsinki than Helsinki? Jasmin: Stadi dweller.

Interviewer: Stadi, yeah.

Jasmin: Mm.

As we have seen (ex. 1, 3, 4), Stadi has been been labelled strongly as a name used by native Helsinkians. Whilst looking for an explanation for this, we should start by considering the early days of Helsinki slang - which, by the way, is generally called Stadi slang. As I have already pointed out, slang was born for over hundred years ago as a linguistic form that combined Finnish and Swedish and was filled with phonetic and lexical features from the Swedish language. The most typical of these features were the initiative double consonant and the phoneme $d$, which are both found in the name Stadi. It could be claimed that Stadi gained popularity at least partly because it was difficult for the rural-born Finnish-speakers to pronounce. They pronounced the name "incorrectly" as Stati or Tati, which slang-speakers found comical or irritating. The slang and the name Stadi as one of its most prominent emblems was loaded with associations that were probably based on very strong stereotypes (Vaattovaara \& Soininen-Stojanov 2006, 226). The affective nature of the name Stadi has been preserved until today.

People's awareness about the ideas associated with the name Stadi and its use can also be seen in that even present-day Helsinki dwellers sometimes use the name in ironical ways. Stadi may turn into, e.g., the humorous forms Stati or Tšadi in the language use of both native and non-native Helsinkians. In example 6 two native men in their forties are discussing the use of names for Helsinki.

(5) Interviewer: What about you others?

Pasi: Well yeah, Helsinki, but then there's this like Timo mentioned this funny name Tšadi which is of course a version of Stadi but you know like 
it's Helsinki and so.

Timo: You know I'm using just Tsadi nowadays. (laughter)

\section{[5] THE SPONTANEUOUS USE OF NAMES}

What is the relationship between the self-reported (metalinguistic) and spontaneous use of name variants in the material? I will answer this question by comparing the informants' descriptions about their name use with their spontaneous use of the names. However, it should be kept in mind that the material available for the study did not provide a very wide or comprehensive picture of how the informants used the names.

There are notable differences between the metalinguistic and spontaneous use of names. When asked, thirteen of the informants said they used Hesa. However, nobody displayed this variant in the material in actual use. Just one informant, Pirjo, born in 1950, who had moved to Helsinki from elsewhere, referred to herself as hesalainen, 'a Hesa dweller'. She was the same woman who claimed that she only used Stadi when asked (which, as a matter of fact, she did not use).

As regards Stadi, ten informants said it was a variant they would use. Of these ten people, just three informants, two natives and one Somali immigrant, used the name even in other than metalinguistic contexts. A Somali immigrant Jasmin (born 1974) uses Stadi spontaneously in the following example.

(6) Interviewer: What comes to your mind when I say Helsinki? What, what like

Jasmin: Helsinki.

Interviewer: Hel-, what is Helsinki or what is Helsinki like?

Jasmin: What's Stadi like? (laughs) Er, it comes, the railway station comes right away. (laughs)

Interviewer: Yeah.

In example 7, Jasmin answers the interviewer's question by a question in which she uses Stadi instead of interviewer's official Helsinki. When asked, Jasmin also says she uses Stadi in addition to Helsinki (see ex. 5).

In the light of my material it would seem that there is a considerable difference between the reported use and actual use of Hesa and Stadi. This may have to do with the fact that the interviewing situation was perceived as an institutional, official discussion, and the informants attempted to use standard language expressions. Yet, it might also be the case that the informants' perception of their own use of the names was different from their actual use.

Usually the informants used the standard form Helsinki to refer to the city. There were no differences between natives and non-natives in this sense, but both 
used Helsinki in numerous examples. In ex. 8, 9 and 10, three native Helsinkians Tuomas (born 1988), Lauri (born 1985), and Noora (born 1984) refer to their home town as Helsinki.

(7) Tuomas: It winds you up if someone's living in Helsinki and they don't know how to take the metro to Vuosaari.

(8) Lauri: But then like the services have been getting poorer and poorer all the time like after we were born in Helsinki.

(9) Noora: Coz there's no, in the end it's [Vuosaari] is so strange. Like there are definitely better places in Helsinki.

Accordingly, the non-native Helsinkians Heidi (born 1985) and Pirjo (born 1950) use the official Helsinki in examples 11 and 12.

(10) Heidi: Well but there's still here in Helsinki there's such small stores here, like we have much bigger ones in Kouvola.

(11) Pirjo: Could it be that the immigrants are active and curious, coz I'm, in fact I'm an immigrant in Helsinki. When I came to Helsinki I took it like you can go anywhere here.

For the Somali informants, too, Helsinki was the typical name variant to use. There were hardly exceptions to this rule; only Jasmin (ex. 7) used Stadi occasionally. In example 13, Abdi (born 1985) talks about Helsinki.

(12) Abdi: And another thing is you know the way you sometimes treat older people. It is a bit, in Helsinki at least, I dunno if it's like that in other places.

\section{[6] CONCLUSIONS}

I hope I have managed to show in this paper that there is quite a difference between the metalinguistic and spontaneous use of names. According to the results of my study, I would suggest that the informants' descriptions do not reflect their ability (or disability) to make observations about their own language use. Rather, the informants' descriptions would seem to indicate their orientation towards the social norms and show how they identify themselves and which social group they regard as prestigious (see also Trudgill (1972); (Labov 2001, 193-194)). The research material even showed how names are strongly connected to the speakers' ideas about their varied identities as Helsinkians. Thus, it could be argued that the speakers' descriptions about their uses of names Helsinki, Hesa and Stadi indicate especially their identity vis-á-vis being a native or non-native. 


\section{REFERENCES}

Ainiala, T. 2004. Pääkaupunkiseudun slanginimistä: Ytimestä Kehärille [Slang names in Helsinki region]. Kielikello 1/2004. 10-12.

Ainiala, T. 2006. Helsingin nimet [Names in Helsinki]. In Juusela K. and K. Nisula (eds.), Helsinki kieliyhteisönä, 100-122. Helsinki.

Ainiala, T. \& J. Vuolteenaho. 2006. How to study urban onomastic landscape? Acta Onomastica XLVII. 58-63.

Hogg, M. A. \& D. Abrams. 1988. Social identifications: a social psychology of intergroup relations and group processes. London: Routledge.

Labov, W. 2001. Principles of linguistic change. Volume ii: Social factors. Oxford: Blackwell.

Paikkala, S. (ed.). 2007. Suomalainen paikannimikirja [Finnish Book of Place names]. Helsinki: Karttakeskus.

Paunonen, H. 1994. The Finnish language in Helsinki. In Nordberg b. (ed.), the sociolinguistics of urbanization: the case of the nordic countries, 223-245. Berlin: Walter de Gryeter.

Paunonen, H. 2000. Tsennaaks stadii, bonjaaks slangii? stadin slangin suursanakirja. [the dictionary of helsinki slang]. Helsinki: WSOY.

Trudgill, P. 1972. Sex, covert prestige and linguistic change in the urban British English of Norwich. Language in Society 1(2). 179-195.

Vaattovaara, J. \& H. Soininen-Stojanov. 2006. Pääkaupunkiseudulla kasvaneiden kotiseuturajaukset ja kielelliset asenteet [Linguistic attitudes among the people grown up in Helsinki region]. In K. juusela and k. nisula (eds.), helsinki kieliyhteisönä, 223-254. Helsinki.

Verkuyten, M. 2005. The social psychology of ethnic identity. Hove: Psychology Press.

AUTHOR CONTACT INFORMATION

Terhi Ainiala

University of Helsinki

PB 3

00014 University of Helsinki

Finland

terhi.ainiala@helsinki.fi 